\title{
CONTINUING PROFESSIONAL DEVELOPMENT TOWARDS TEACHERS' PERFORMANCE AT VOCATIONAL SECONDARY SCHOOLS IN SURAKARTA
}

\author{
Isti Setya Rini \\ Universitas Sebelas Maret \\ Ismi Dwi Astuti Nurhaeni \\ Universitas Sebelas Maret \\ Cicilia Dyah Sulistyanngrum Indrawati \\ Universitas Sebelas Maret
}

\begin{abstract}
Continuing Professional Development is a program from the government so that teachers can develop their performance. Continuing Professional Development includes: self-development, scientific publications, and innovative work. This study aims to determine the effect of Sustainable Professional Development (self-development, scientific publications, and innovative work) on the performance of vocational business and management teachers in Surakarta. This study uses a quantitative method with Structural Equation Modeling Partial Least Square (SEM-PLS) analysis. The study sample was 158 business and management vocational teachers in Surakarta, Indonesia. The results of the study show that 1) self-development has a positive and significant influence on teacher performance of 0.333 and the statistical value of $T$ is $5.028 \geq 1.96$; 2) scientific publications have a positive and significant effect on teacher performance of 0.225 and $T$ statistical values of $1.763 \leq 1.96$; and 3) innovative works have a positive and significant effect on teacher performance of 0.282 and the value of $T$ statistics is 1.810 .91.96. Therefore, vocational business and management teachers need to improve professional development through scientific publications and innovative work.
\end{abstract}

Keywords: self-development, scientific publication, innovative work, and teachers' performance

Permalink: $h t t p: / / d x . d o i . o r g / 10.21831 / j p v . v 9 i 1.21644$

Contact Isti Setya Rini

$\ominus$ Univ istisetyarini@student.uns.ac.id Universitas Sebelas Maret, Jl. Ir. Sutami No.36 A, Pucangsawit, Jebres, Kota Surakarta, Jawa Tengah 57126, Indonesia 


\section{INTRODUCTION}

Education has an important role for the progress of a nation for example by producing graduates who have high Human Resources (HR). This cannot be separated from the role of the teacher in realizing the goals of national education. Therefore, the government is now very serious in handling quality improvement in the field of education. One effort to improve the quality of education is by increasing teacher performance (Susanto, 2012, p. 198; Warastuti \& Usman, 2013, p. 375; Mahmud, 2016, p. 19; Sutiasih, 2017, p. 98). Teachers are required to have four basic competencies to meet high performance (Destiana \& Soenarto, 2014: p. 286). The basic competencies possessed by the teacher include pedagogic, professional, social, and personality competencies. Especially teachers who teach in vocational education, they are required to have high performance to prepare and develop human resources who are able to work professionally in their fields. Vocational High School Education (SMK) must be able to keep up with the technological development of the business world or the industrial world.

The improvement of the performance of vocational teachers is still below average (Sutiasih, 2017, p. 98). In Surakarta, based on the results of the 2015 Teacher Competency Test (Uji Kompetensi Guru/UKG), out of 10,900 teachers who participated in UKG $42 \%$ of them received grades below the specified standard, namely 831 vocational school teachers. This shows that 831 vocational school teachers in Surakarta City both public and private vocational schools have not fulfilled qualifications as professional teachers (Wardhani, 2017, p. 79). According to Murtini, Sawiji, \& Rapih (2017, p. 1) several factors that cause low UKG scores include lack of professional competence, lack of pedagogical competencies, lack of IT mastery, and too much workload that results in low teacher performance reflected in UKG scores. This means that the teacher has not carried out his performance optimally, so he needs to improve his professionalism as a teacher.

Teachers must always develop their competence and professionalism in order to stay awake and always increase in accordance with the needs and demands that develop. Therefore, the government has made efforts to improve teacher professionalism in Indonesia. The government program is contained in the Regulation of the Minister of State for Administrative Reform and Bureaucratic Reform Number 16 of 2009, namely Continuing Professional Development. Continuing Professional Development is carried out in accordance with the teacher's need to achieve professional competency standards or improve teacher competency above standards while having implications for obtaining credit scores for teacher promotion/functional positions. The principles of Continuing Professional Development are: (1) professional development of sustainability is the individual's own needs; (2) need to be carried out Continuingly and always be proactive to improve self-performance; and (3) awareness to develop professionalism (Sujianto, 2013, p. 160).

Continuing professional development as a strategy that can facilitate the development of teachers to meet the contemporary needs of the education system (Sahlberg, 2011, p. 170). Teacher development includes systematically planned experiences to encourage professional growth and development (Huang, 2016, p. 926). If Continuing professional development is carried out Continuingly, the impact on teacher performance is high. But in reality, there are still many teachers who have not improved their professionalism well and Continuingly. According to Susanto (2012, p. 198) there are still few teachers who conduct classroom action research or scientific papers to improve their professionalism. Continuing Professional Development includes three things; namely self-development, scientific publications, and innovative works. Self-development includes the participation of teachers in functional training, attending seminars or workshops and collective activities that enhance teacher professional competence. Scientific publications include the participation of teachers in conducting scientific publications or research results and publicizing textbooks or enrichment books. While innovative works include activities undertaken by the teacher in finding innovations in the form of appropriate technology for subjects taught, creating or modifying learning aids, and following the development of standardized questions and updating the material being taught.

In connection with this, there is a need for in-depth research on Continuing professio- 
nal development. But in this study more indepth about self-development, scientific publications, and innovative work to improve teacher performance, especially business and management vocational teachers in Surakarta. The purpose of this study was to determine (1) the effect of self-development on teacher performance in vocational schools throughout Surakarta; (2) the influence of scientific publications on teacher performance in Vocational Schools in Surakarta; and (3) the influence of innovative work on teacher performance in Vocational Schools in Surakarta.

\section{RESEARCH METHOD}

The method used in this research is quantitative with survey methods. Because this research uses a quantitative approach of the survey method, questionnaires are used to obtain sample data taken from the population. Then, the data that have been collected processed by using the hypothesis testing. They are analyzed by using Structural Equation Modeling (SEM) analysis which is supported by Partial Least Square (PLS) computer program version 3.0. The result of the analyzing data are analyzed based on the existing research variables. The existing variables are self-development "pengembangan diri", scientific publication "publikasi ilmiah", innovative work "karya inovatif", and teachers' performance "kinerja guru".

The sample is part of the number and characteristics possessed by the population (Sugiyono, 2010, p. 389). The sampling technique used proportional random sampling technique by lottery. Proportional random sampling is the technique of taking proportions to obtain a representative sample, taking subjects from each stratum or regionally balanced or comparable in each region (Arikunto, 2006, p. 127). The details of the number of samples are as follows:

Table 1. Details of the number of samples

\begin{tabular}{lcc}
\hline \multicolumn{1}{c}{ School } & $\begin{array}{c}\text { Number of } \\
\text { Teacher } \\
\text { Populations }\end{array}$ & $\begin{array}{c}\text { Number } \\
\text { of } \\
\text { Samples }\end{array}$ \\
\hline SMKN 1 Surakarta & 65 & 39 \\
SMKN 3 Surakarta & 85 & 51 \\
SMK Batik 1 Surakarta & 60 & 36 \\
SMK Batik 2 Surakarta & 53 & 32 \\
TOTAL & 263 & 158 \\
\hline
\end{tabular}

Based on the table above, the sample in this research were 158 vocational high schools of business and management teachers in Surakarta. The sample was taken by using Slovin.

Data analysis techniques was Structural Equation Modeling (SEM) with Smart PLS (Partial Least Square) software. In PLS Path Modelling, there are 2 models namely the outer model and the Inner model. Testing criteria are carried out on both models.

\section{Outer model (Evaluation of Measurement Model)}

This model specifies the relationship between latent variables and their indicators or it can be said that the outer model defines how each indicator relates to its latent variables. Tests carried out on the outer model are: (a) Convergent Validity. The convergent validity value is the value of the loading factor on the latent variable with the indicators. Expected value is $>0.7$; (b) Discriminant Validity. This value is a cross loading value factor that is useful to find out whether the construct has adequate discriminant. Comparing the loading value in the intended construct must be greater than the loading value with another construct; (c) Average Variance Extracted (AVE). Expected AVE value is > 0.5; (d) Composite Reliability. The data that has composite reliability $>0.8$ sounds high reliability.

\section{Inner Model (Structural Model)}

Tests on structural model are carried out to examine the relationship between latent constructs. Some tests for structural model are: (a) $\mathrm{R}$ Square on endogenous constructs. The $\mathrm{R}$ Square value is the coefficient of determination in the endogenous construct. According to Ghozali (2011), the $\mathrm{R}$ square value is 0.67 (strong), 0.33 (moderate) and 0.19 (weak); (b) Estimate for Path Coefficients, is the value of the path coefficient or the magnitude of the relationship or the effect of the latent construct carried out by the bootstrapping procedure.

The research was designed to determine the effect of three independent variables (exogenous), namely self-development, scientific publications and innovative work and one dependent variable (endogenous), namely teachers' performance. The effect constellation between exogenous variables and endogenous variables can be described as the research design in the Figure 1. 


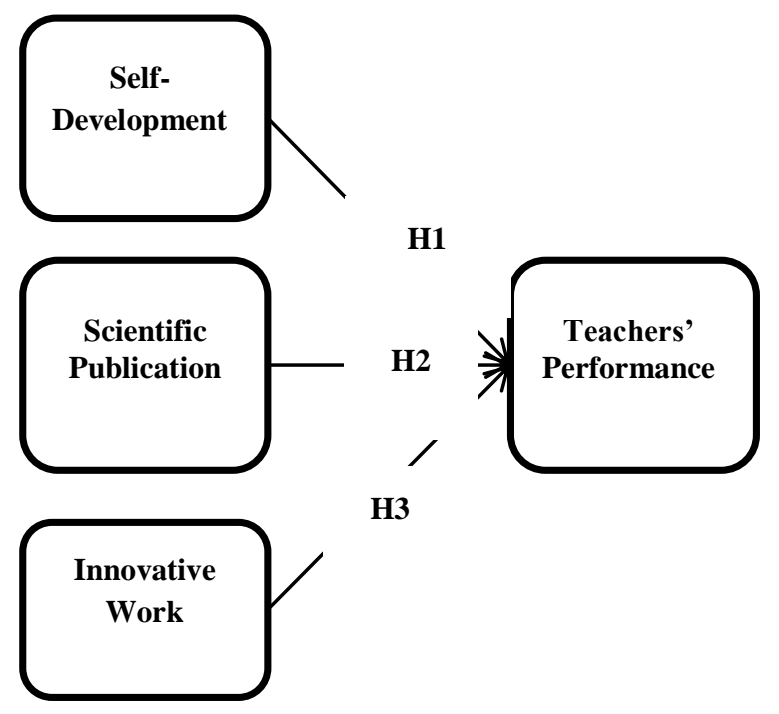

Figure 1. Hypothesis

Research Hypothesis

H1 : There is an effect of self-development towards teachers' performance at Vocational High Schools in Surakarta.

$\mathrm{H} 2$ : There is an effect of scientific publication towards teachers' performance at Vocational High Schools in Surakarta.

H3 : There is an effect of innovative work towards teachers' performance at Vocational High Schools in Surakarta.

\section{RESULTS}

\section{Data Description}

\section{Description of Teachers' Performance Data}

Data on teachers' performance variable were obtained by distributing questionnaires to 158 teachers. The results showed the lowest score of 8 , the highest score of 16 , an average of 13.13 and a standard deviation of 2.048 . Questionnaire of teachers' performance variable consists of 4 questions whose measurements are assessed by alternative answers with a score of 1-4. If it is calculated by the percentage, the obtained highest score is $4 \times 4 \times 158$ $=2528$. The number of scores of the results of data collection of teachers' performance variable is 2075 . Thus, the percentage of teachers' performance variable is (2075: 2528) x $100 \%$ $=82.08 \%$. The frequency distribution of the score obtained from the teacher's performance can be seen in the Figure 2.

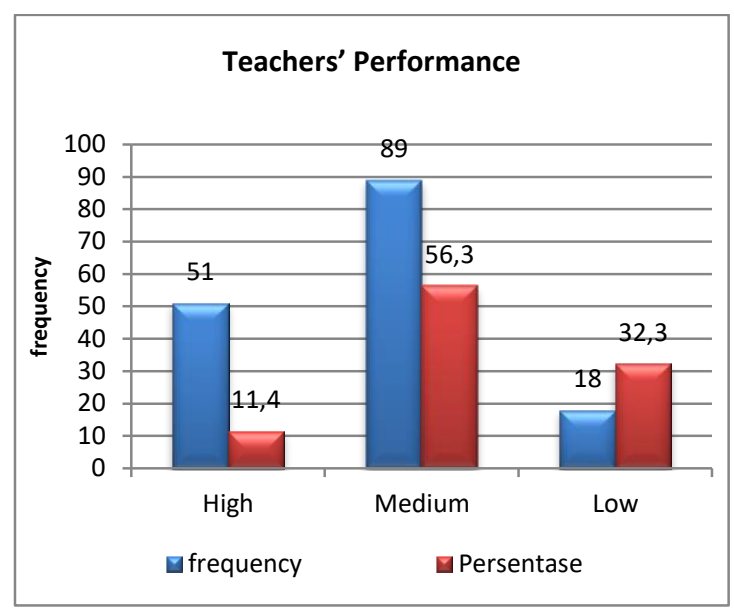

Figure 2. Teacher' Performance Trends Categories

\section{Description of Self-Development Data}

Self-development variable data was obtained by distributing questionnaires to 158 teachers. The results showed that the lowest score was 3 , the highest score was 12 , the average was 5.91 and a standard deviation of 2.116. The self-development variable questionnaire consists of 3 questions whose measurements are assessed with alternative answers ranging 1-4. If it is calculated by percentage, the obtained highest score is $3 \times 4 \times 158=1896$. The number of scores of the results of data collection of self-development variable is 934 . Thus, the percentage of self-development variable is $(934: 1896) \times 100 \%=49.26 \%$. The frequency distribution of the score obtained from the self-development can be seen in the Figure 3.

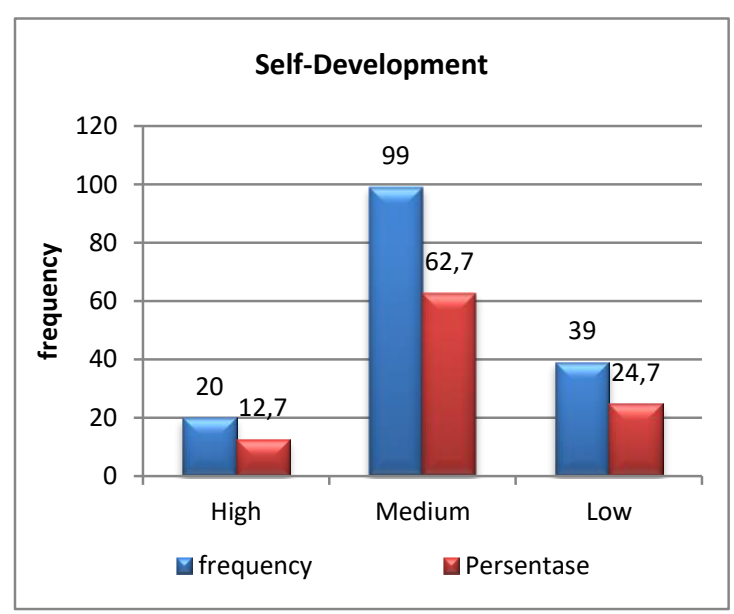

Figure 3. Self-Development Trends Categories 


\section{Description of Scientific Publication Data}

Scientific publication variable data was obtained by distributing questionnaires to 158 teachers. The results showed that the lowest score was 3 , the highest score was 12 , the average was 5.36 and a standard deviation of 2.664. The Scientific publication variable questionnaire consists of 3 questions whose measurements are assessed with alternative answers ranging 1-4. If it is calculated by percentage, the obtained highest score is $3 \times 4 \times 158=1896$. The number of scores of the results of data collection of scientific publica-tion variable is 847 . Thus, the percentage of scientific publication variable is $(847: 1896) \times 100 \%=44.67 \%$. The frequency distribution of the score obtained from the scientific publication can be seen in the Figure 4.

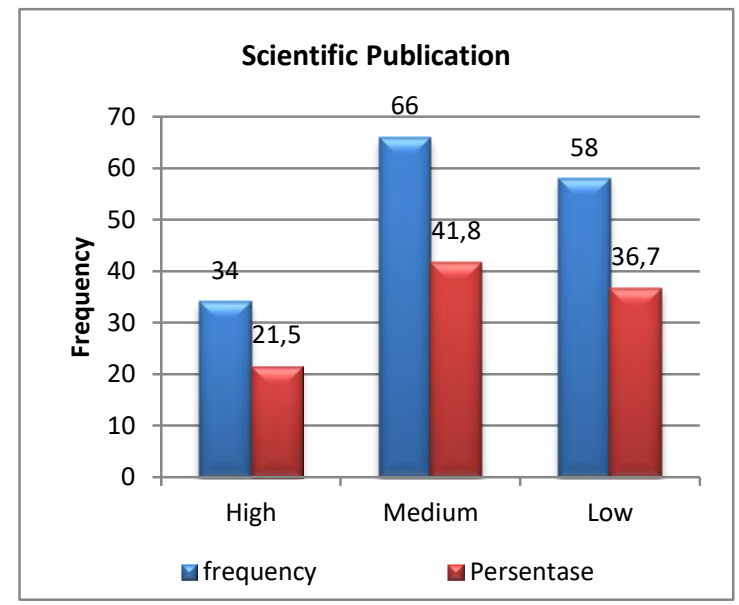

Figure 4. Scientific Publication Trend Category

\section{Description of Innovative Work Data}

Data of innovative work variable was obtained by distributing questionnaires to 158 teachers. The results showed that the lowest score was 3, the highest score was 12 , the average was 5.86 and a standard deviation of 2.314. The innovative work variable questionnaire consists of 3 questions whose measurements are assessed with alternative answers ranging 1-4. If it is calculated by the percentage, the obtained highest score is $3 \times 4 \times 158=$ 1896. The number of scores of the results of data collection of innovative work variable is 926. Thus, the percentage of innovative work variable is $(926: 1896) \times 100 \%=48.84 \%$. The frequency distribution of the score obtained from the innovative work can be seen in the Figure 5.

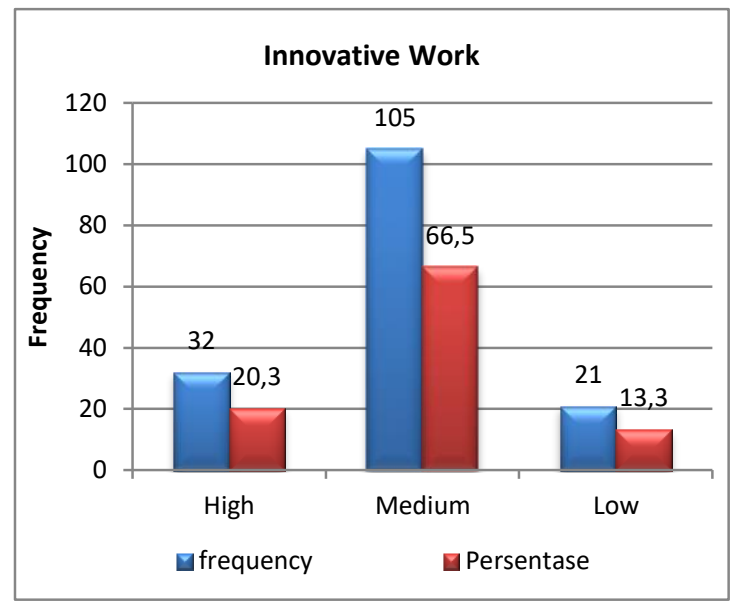

Figure 5. Innovative Work Trends Categories

\section{Outer Model Evaluation}

Convergent Validity

Test parameter of convergent validity in the PLS measurement model with reflexive indicator can be measured based on loading factor with rule of thumb $>0.7$. The loading factor value with rule of thumb between 0.5 0.6 can still be used (Yamin \& Kurniawan, 2011, p. 202; Haryono, 2017, p. 405) or using AVE and Communality $>0.5$ parameters or $T$ Statistics $\geq 1.96$ and $\mathrm{P}$ Value $\leq 0.05$. The results of the correlation between indicators and their constructs are shown in the Table 2.

This research is a confirmatory research. Therefore, convergent validity has a provision that the value of loading factor is more than 0.7 (Ghozali, 2014). Based on the table above, it is explained that all questionnaires of the research variables are valid. This is based on all questionnaire items of research variables namely self-development, scientific publication, innovative work, and teachers' performance showing that the value of loading factor is more than 0.7 . It means that the T-Statistics value is $\geq$ 1.96. 
Table 2. Convergent Validity

\begin{tabular}{lcccc}
\hline & $\begin{array}{c}\text { Original } \\
\text { Sample }\end{array}$ & $\begin{array}{c}\text { Sample } \\
\text { Mean }\end{array}$ & $\begin{array}{c}\text { Standard } \\
\text { Deviation }\end{array}$ & T Statistics \\
\hline KG1 <- Teachers' Performance & 0.705 & 0.692 & 0.070 & 10.071 \\
KG2 <- Teachers' Performance & 0.785 & 0.772 & 0.084 & 9.326 \\
KG3 <- Teachers' Performance & 0.772 & 0.756 & 0.089 & 8.683 \\
KG4 <- Teachers' Performance & 0.840 & 0.841 & 0.043 & 19.444 \\
PD1 <- Self-Development & 0.851 & 0.848 & 0.031 & 27.366 \\
PD2 <- Self-Development & 0.811 & 0.807 & 0.039 & 20.653 \\
PD3 <- Self-Development & 0.773 & 0.764 & 0.075 & 10.284 \\
PI1 <- Scientific Publication & 0.800 & 0.725 & 0.273 & 2.931 \\
PI2 <- Scientific Publication & 0.953 & 0.861 & 0.352 & 2.708 \\
PI3 <- Scientific Publication & 0.799 & 0.723 & 0.298 & 2.686 \\
KI1 <- Innovative Work & 0.730 & 0.692 & 0.153 & 4.757 \\
KI2 <- Innovative Work & 0.909 & 0.892 & 0.097 & 9.343 \\
KI3 <- Innovative Work & 0.792 & 0.682 & 0.121 & 5.705 \\
\hline
\end{tabular}

\section{Discriminant Validity}

Discriminant validity explains the ability of each indicator to make a distinction between its constructs and other constructs. If an indicator is incorporated into another construct, the indicator has good discriminant. From the table of cross loading, the overall construct of the constructor is stated to have good discriminant. It means that each construct has the highest relationship with its own variable. There is no greater specific indicator that is not from the same variable (Ghozali, 2011, p.25). Output of discriminant validity from the results of the data processing can be seen in the following Table 3.

Table 3. Discriminant Validity

\begin{tabular}{lcccc}
\hline & $\begin{array}{c}\text { Teachers' } \\
\text { Performance }\end{array}$ & $\begin{array}{c}\text { Self- } \\
\text { Development }\end{array}$ & $\begin{array}{c}\text { Scientific } \\
\text { Publication }\end{array}$ & $\begin{array}{c}\text { Innovative } \\
\text { Work }\end{array}$ \\
\hline KG1 & 0.705 & 0.186 & 0.103 & 0.224 \\
KG2 & 0.785 & 0.212 & 0.059 & 0.087 \\
KG3 & 0.772 & 0.195 & 0.007 & 0.115 \\
KG4 & 0.840 & 0.463 & 0.223 & 0.351 \\
PD1 & 0.379 & 0.851 & 0.220 & 0.316 \\
PD2 & 0.320 & 0.811 & 0.511 & 0.541 \\
PD3 & 0.221 & 0.773 & 0.369 & 0.441 \\
PI1 & 0.030 & 0.247 & 0.800 & 0.718 \\
PI2 & 0.187 & 0.453 & 0.953 & 0.749 \\
PI3 & 0.096 & 0.310 & 0.799 & 0.633 \\
KI1 & 0.099 & 0.426 & 0.667 & 0.730 \\
KI2 & 0.322 & 0.381 & 0.648 & 0.909 \\
KI3 & 0.174 & 0.500 & 0.587 & 0.792 \\
\hline
\end{tabular}

Based on the table above, the result of cross loading showed that the latent construct correlation in predicting indicators in each variable was much better than other variable indicators. Thus, the test of discriminant validity has been fulfilled. Then, it can examine the comparison of the root value of AVE and the latent variable correlation coefficient with the correlation between constructs.

\section{Average Variance Extracted (AVE)}

AVE describes the average variance or extracted discriminant in each indicator so that the ability of each item in dividing measurements with others can be known. AVE value that is equal to or above 0.50 indicates a good convergent.

Table 4. Average Variance Extracted (AVE)

\begin{tabular}{lcc}
\hline & AVE & $\begin{array}{c}\text { Root of } \\
\text { AVE }\end{array}$ \\
\hline Teachers' Performance & 0.604 & 0.777 \\
Self-Development & 0.660 & 0.812 \\
Scientific Publication & 0.729 & 0.854 \\
Innovative Work & 0.613 & 0.783 \\
\hline
\end{tabular}

Based on the Table 4, the result showed that the root value of AVE was greater than the AVE value. AVE value of the teachers' performance variable is 0.604 . AVE value of selfdevelopment variable is 0.660 . AVE value of scientific publication variable is 0.729 . AVE 
value of innovative work variable is 0.613 . At the critical limit of 0.5 , the indicators in each construct are valid with the other items in one measurement. It means that discriminant validity has been fulfilled.

\section{Composite Reliability}

Composite reliability measures internal consistency and its value must be above 0.6 (Ghozali, 2011, p. 27). The results of composite reliability can be seen in Table 5 .

Table 5. Composite Reliability

\begin{tabular}{|c|c|c|}
\hline & $\begin{array}{l}\text { Cronbach's } \\
\text { Alpha }\end{array}$ & $\begin{array}{l}\text { Composite } \\
\text { Reliability }\end{array}$ \\
\hline Teachers' Development & 0.802 & 0.859 \\
\hline Self-Development & 0.749 & 0.853 \\
\hline Scientific Publication & 0.837 & 0.889 \\
\hline Innovative Work & 0.714 & 0.889 \\
\hline
\end{tabular}

Based on the Table 5, it can be explained that the value of composite reliability is good for the construct of self-development, scientific publication, innovative work, and teachers' performance. All of their values are above 0.60 . Thus, it can be concluded that the construct has good reliability.

\section{Inner Model Evaluation (Structural Model Evaluation)}

The evaluation of the structural model was analyzed by looking at the significance of the relationship between the constructs shown by t-statistics.

\section{Hypothesis Testing}

Testing the hypothesis to answer the research hypothesis can be seen in t-statistics in the following Table 6. as follows:

Based on the Table 6, it can be explained

Fisrt, Self-development has a positive and significant effect on teachers' performance.
Based on the results of testing the Original Sample value of 0.333 and the T-statistics value of 5.028 which means greater than 1.96, the hypothesis stating that self-development has a positive and significant effect on teachers' performance can be acceptable.

Second, Scientific publication has a positive and significant effect on teachers' performance. Based on the results of testing the Original Sample value of 0.225 and the $\mathrm{T}$ statistics value of 1.763 which means smaller than 1.96 , the hypothesis stating that scientific publication has a positive but not significant effect on teachers' performance can be unacceptable.

Third, Innovative work has a positive and significant effect on teachers' performance. Based on the results of testing the Original Sample value of 0.282 and the T-statistics value of 1.810 which means smaller than 1.96 , the hypothesis stating that innovative work has a positive but not significant effect on teachers' performance can be unacceptable.

\section{Determination Coefficient $\left(\boldsymbol{R}^{2}\right)$}

The structural model is evaluated by looking at the value of determination coefficient $\left(\mathrm{R}^{2}\right)$ for each endogenous latent variable as the predictive power of the structural model. $\mathrm{R}$ Square in this study amounted to 0.184 and R Square Adjusted 0.168. Based on this shows that the value of $\mathrm{R}$ Square for teacher performance variables of 0.184 or $18.4 \%$ can be explained by self-development, scientific publications and innovative works, where the remainder is influenced by other variables not examined in this study. The value of $\mathrm{R}$ Square or determination coefficient for endogenous construct in this research is 0.184 . It showed that the effect of self-development, scientific publication, and innovative work towards teachers' performance was weak.

Table 6. Inter-Construction

\begin{tabular}{lccccc}
\hline & Original & Sample & Standard & T & P Values \\
& Sample & Mean & Deviation & Statistics & \\
\hline Self-Development -> Teachers' Performance & 0.333 & 0.342 & 0.066 & 5.028 & 0.000 \\
Scientific Publication -> Teachers' Performance & 0.225 & 0.176 & 0.128 & 1.763 & 0.079 \\
Innovative Work -> Teachers' Performance & 0.282 & 0.281 & 0.137 & 1.810 & 0.058 \\
\hline
\end{tabular}




\section{Discussion}

\section{Effect of Self-Development towards Teach- ers' performance}

Based on spread questionnaires, the level of achievement of self-development from the results of data collection is $49.26 \%$. This number has not reached the maximum score and can still be increased. Teachers have not been maximal in joining the functional training activities. They rarely became speakers at education seminars. They were also less active in teachers' subject discussion activities. On the other hand, the results of the data testing showed that the original sample value of the selfdevelopment variable is 0.333 . It showed that self-development had a positive effect on teachers' performance. When self-development increases, it will improve teachers' performance as well. The t-statistics value of 5,028 $\geq$ 1.96 means that self-development was significant with teachers' performance. Based on the original sample value and the t-statistics value, it showed that self-development had a positive and significant effect towards teachers' performance.

Based on the results of interviews with vocational high school teachers related to selfdevelopment, it showed that they often attended seminars, workshops, and MGMP activities because of orders from the principal and aims of increasing their performance credit figures. Teachers often took part in training and education because there were demands to attend a minimum of 32 training courses. They also still actively attended teachers' subject discussion routine activities. The results of Maksum's study $(2015$, p. 76$)$ showed that the results of self-development activities were carried out for some certain teachers, thus not all of teachers.

The same thing was also done by Danim's research (2011, p. 95) showing that the quality of teachers in self-development activities was still low. Teachers were less active in training activities, educational seminar activities, workshops, and MGMP activities. In conclusion, self-development carried out by vocational high school teachers in Surakarta will be able to improve teachers' performance. The results of a study conducted by Althauser (2015, p. 111) supporting this study explain that a Continuing professional development program can improve the self-development of a teacher. Continuing self-development to improve teacher performance in accordance with the objectives of Continuing professional development.

\section{Effect of Scientific Publication towards Teachers' performance}

Based on spread questionnaires, the level of achievement of self-development from the results of data collection is $44.67 \%$. This number has not reached the maximum score and can still be increased. Teachers rarely wrote scientific papers. There were still many teachers who have never done scientific or research publications. Teachers also rarely published textbooks or enrichment books. On the other hand, the results of the data testing showed that the original sample value of 0.225 indicated that scientific publication had a positive effect towards teachers' performance. When scientific publication increases, it will improve teachers' performance as well. The t-statistics value of $1.763 \leq 1.96$ means that scientific publication was not significant with teachers' performance. Based on the original sample value and the t-statistics value, it showed that scientific publication had a positive but not significant effect towards teachers' performance.

Based on the interviews conducted by the researcher, it showed that teachers rarely did scientific publications or even publication of textbooks. This is in line with the research conducted by Alifa \& Rosidah (2017, p. 62). The results of the research indicated that the activities of teachers in conducting scientific publications were still low. Teachers were less active in scientific forums, did less research, and did less scientific publication or research. In conclusion, scientific publication had a positive effect towards teachers' performance. This means that the existing scientific publication will improve the intention of the teachers' performance, but it is still quite low because it is not significant. Those results indicated that teachers' expectation on teachers' performance were higher than scientific publication conducted by vocational high school teachers in Surakarta.

Widodo, Supardi, Suyoto, \& Wismanto's research $(2014$, p. 105) said that the teachers had less understanding towards concept and principal written of a classroom action research study which will be published in a form of scientific journal, not all of teachers did 
reflecting-thinking through portfolio (a record of teachers' work by time to time), there were no counselors to help them in writing an article of a classroom action research results. Wuryandini (2014, p. 117) said that there were still many problems faced by teachers related to scientific publications, they are teachers had different characteristics (individuals and environment), a scientific publication event which involved a presentation of the scientific research results, textbooks and teachers' book publication was not done effectively in a scientific forum, the teachers got a partial understanding about scientific publication, the teachers' preparation and commitment to join workshop were still less.

\section{Effect of Innovative Work towards Teachers' performance}

Based on spread questionnaires, the level of achievement of self-development from the results of data collection is $48.84 \%$. This number has not reached the maximum score and can still be increased. Teachers rarely innovated in finding appropriate technology for the learning materials. They rarely modified or created teaching aids. They also rarely modified learning methods. Besides, they were less active in developing compilation of learning process standards and assessments and in compiling grid of examination questions. On the other hand, the results of the data testing showed that the original sample value of 0.282 indicated that innovative work had a positive effect on teachers' performance. When innovative work increases, it will improve teachers' performance as well. T-statistics value of 1.810 $\leq 1.96$ means that innovative work was insignificant with teachers' performance. Based on the original sample value and the t-statistics value, innovative work had a positive but not significant effect on teachers' performance. Based on the interviews, the researcher indicated that vocational high school teachers were still lacking in developing the capabilities of their innovative work. Teachers preferred simple and available learning media. The reason was that they already had crowded teaching burden. It did not allow them to create innovative learning media.

This is reinforced by a research conducted by Sujianto (2013, p. 160). The result of the research showed that teachers were still lacking in finding or creating appropriate technology.
It was caused by some factors. Teachers preferred available learning media. They were not ready to develop teaching materials either. Besides, they had limited abilities and unsupportive facilities and infrastructure. In conclusion, innovative work had a positive effect towards teachers' performance. This means that the existing innovative work will improve the intention of the teacher's performance, but it is still quite low because it is not significant. Those results indicated that teachers' expectation on teachers' performance were higher than innovative work carried out by vocational high school teachers in Surakarta. The results of this study stated that teachers' ability to write a scientific journal is still low. In contrary Dudung, Priyanto, \& Lubi (2014, p. 21) explained that teachers were able to do self-development in writing a scientific journal as preparation to get a higher level of their career. Yani (2011, p. 217) in her dissertation said that the teachers' ability in writing an innovative scientific work by involving technology was still low. It was caused that the media and tools offered were still limited. The school offered around 25\% $50 \%$ tools and media. It means that the schools were not able to provide facilities to train its teachers. It can be seen from tools and media. They provided conventional method only such as globe, maps, pictures, and LKS.

\section{CONCLUSION}

Based on the original sample value and the t-statistics value, it showed that selfdevelopment had a positive and significant effect towards teachers' performance. It can be concluded that self-development carried out by vocational high school teachers in Surakarta will improve teachers' performance.

Based on the original sample value and t-statistics value, it showed that scientific publication had a positive but not significant effect towards teachers' performance. It can be concluded that scientific publication had a positive effect towards teachers' performance. This means that the existing scientific publication will improve the intention of the teacher's performance, but it is still quite low because it is not significant. Those results indicated that teachers' expectation on teachers' performance were higher than scientific publication conducted by vocational high school teachers in Surakarta. 
Based on the original sample value and the t-statistics value, it showed that innovative work had a positive but not significant effect towards teachers' performance. It can be concluded that the innovative work had a positive effect towards teachers' performance. This means that the existing innovative work will improve the intention of the teacher's performance, but it is still quite low because it is not significant. Those results indicated that teachers' expectation on teachers' performance were higher than innovative work carried out by vocational high school teachers in Surakarta.

Based on the results of this research, there are three suggestions to increase teachers' participation in Continuing professional development consisting of self-development, scientific publication, and innovative work: (1) Teachers utilize and look for training and education opportunities, often attend education seminars and workshops related to their fields, and are more active in MGMP activities; (2) Teachers are expected to be more active in scientific forums, actively conduct scientific publications or research results; (3) Teachers utilize programs that can enhance their professionalism by producing innovative works.

\section{REFERENCES}

Alifa, U, N., \& Rosidah. (2017). Kualitas pengembangan profesi guru di SMK Muhammadiyah 1 Wates. Jurnal Pendidikan Administasi Perkantoran, 6(1). 49-64.

Althauser, K. (2015). Job-embedded professional development: its impact on teacher self-effiacy and student performance. Teacher Development: An International Journal of Teachers' Professional Development, 19(2). 210225.

Arikunto, S. (2010). Prosedur penelitian suatu pendekatan praktik. Jakarta: Rineka Cipta.

Danim, S. (2011). Pengembangan profesi guru. Jakarta: Kencana Prenada Media Group.

Destiana, B., \& Soenarto, S. (2014). Faktor determinan pemanfaatan tik dan pengaruhnya terhadap kinerja guru SMK di Kabupaten Gunungkidul. Jurnal
Pendidikan Vokasi, 4(3).

doi:https://doi.org/10.21831/jpv.v4i3.25 55

Dudung, A., Priyanto, S., \& Lubi., A. (2014). Pelatihan praktik mesin CNC bagi guruguru SMK Jakarta. Sarwahita, 12(1). 1925

Ghozali, I. (2011). Aplikasi analisis multivariate dengan program IBM SPSS 19. Semarang. Universitas Diponegoro.

Ghozali, I. (2014). Structural equation modeling, metode alternatif dengan partial least square (PLS). Semarang : Badan Penerbit Universitas Diponegoro.

Haryono, S. (2017). Metode SEM untuk Penelitian Manajemen AMOS LISREL $P L S$. Luxima Metro Media.

Huang, B. R. (2016). Transformation and framework of teacher professional development in Taiwan. Policy Futures in Education, 14(7), 926-942.

Kementerian Negara Pendayagunaan Aparatur Negara dan Reformasi Birokrasi.

Peraturan Menteri Negara Pendayagunaan Aparatur Negara dan Reformasi Birokrasi Nomor 16 Tahun 2009 tentang Jabatan Fungsional Guru dan Angka Kreditnya (2009).

Mahmud, E. N. (2016). Pengaruh Kepemimpinan Kepala Sekolah dan Kompetensi Guru terhadap Kinerja Guru Di UPTD Sekolah Dasar Kecamatan Cilamaya. Jurnal Ekonomi \& Bisnis, I(2). 19-32.

Maksum. (2015). Pelaksanaan Pengembangan Keprofesian Berkelanjutan Guru Kelas SD Negeri 2 Tarakan. Jurnal Kebijakan dan Pengembangan Pendidikan, 3(1). 75-81.

Murtini, W., Sawiji, H., \& Rapih, S,. (2017). Continuing Professional Development For Teachers: What is needed?. Prosiding International Conference on Educational Science. UPI

Sahlberg, P. (2011). Finnish Lessons: What can the world learn from the educational change in Finland? New York: Teachers College Press. 1(3). 167-170.

Sugiyono. (2010). Metode penelitian 
pendidikan pendekatan kuantitatif, kualitatif, dan $R \& D$. Bandung: Alfabeta.

Sujianto. (2013). Pengembangan

Profesionalitas

Berkelanjutan/Continuing

Professionality Development (CPD)

Guru Bersertifikat Pendidik di SMK

Rumpun Teknologi se-Malang Raya.

Jurnal Pendidikan Sains, 1(2). 159-170.

Susanto, H. (2012). Faktor-faktor yang mempengaruhi kinerja guru sekolah menengah kejuruan. Jurnal Pendidikan Vokasi, 2(2).

doi:https://doi.org/10.21831/jpv.v2i2.10 28

Sutiasih, A. D. (2017). Kinerja guru SMKN

Kota Padang (studi kasus : SMKN

kelompok teknologi dan rekayasa).

Jurnal Pendidikan dan Teknologi

Informasi, 4(1), 97-103.

Warastuti, W. P., \& Usman, H. (2013).

Kinerja guru SMK program keahlian teknik bangunan di Daerah Istimewa Yogyakarta.Jurnal Pendidikan Vokasi, 3(3).

doi:https://doi.org/10.21831/jpv.v3i3.18 50

Wardhani, F, R. (2017). Analisis Kompetensi Guru Berbasis Uji Kompetensi Guru (UKG) Pada Guru Sekolah Menengah
Kejuruan (SMK) Bidang Keahlian Administrasi Perkantoran Di Surakarta Tahun Ajaran 2015/2016. Jurnal Informasi Dan Komunikasi Administrasi Perkantoran, 1(1). 75-84.

Widodo, S. Suyoto, Supardi, Wismanto, A. (2014). Peningkatan Kompetensi Guru Profesional Berbasis Penulisan Artikel Hasil Penelitian Tindakan Kelas (PTK) bagi Guru Anggota PGRI di Kabupaten Purworejo. Jurnal Pengabdian Kepada Masyarakat, 5(1), 1-11. Retrieved from http://journal.upgris.ac.id/index.php/edimas/article/view/730

Wuryandini, E. (2014). Analisis Permasalahan Dan Kebutuhan Pengembangan Keprofesionalan Berkelanjutan Guru SMK BidangKeahlian Bisnis dan Manajemen Pasca Sertifikasi di Kota Kota Semarang. Jurnal Manajemen Pendidikan, 9(2): 108 - 119.

Yamin, S. \& Kurniawan, H. (2009). Structural Equation Modeling. Jakarta: Salemba Infotek.

Yani, A. (2011). Pengembangan model meaningful learning untuk meningkatkan daya nalar siswa melalui aplikasi mind map pada mata pelajaran Geografi di SMA, Retrieved 13 Agustus 2018 from http://repository.upi.edu/disertasiview.ph p?export=word\&no_disertasi $=156$ 